\title{
Evaluation of Physical, Chemical and Sensory Properties of Turkish Flat Breads (Bazlama and Yufka) Supplemented with Lupin, Buckwheat and Oat Flours
}

\author{
Hace $r$ Levent ${ }^{1, *}$, Ne rmin Bilgiçli ${ }^{2}$ \\ ${ }^{1}$ Mut Vocational School for Higher Education, Mersin University, Mersin, 33600, Turkey \\ ${ }^{2}$ Department of Food Engineering, A gricultural Faculty, Selçuk University, Kony a, 42049, Turkey
}

\begin{abstract}
In this research, lupin, buckwheat and oat flours (30\%) and their blends $(15 \%+15 \%$ and $10 \%+10 \%+10 \%)$ were used in Turkish flat breads (bazlama and yufka) p roduction for nutritional enrichment. Some physical (diameter, thickness, spread ratio and color), chemical (mo isture, ash, crude protein and mineral content) and sensory properties of bread samples were investigated. High protein levels of lupin flour(LF) increased the protein content of bazla ma and yufka samples from $11.85 \%$ and $11.62 \%$ to $19.97 \%$ and $19.74 \%$, respectively. The highest ash content was obtained with addition of $30 \%$ buckwheat flour (BF) in flat breads. Generally all of the minerals in breads containing LF, BF and oat flour (OF) or their blends were found significantly higher $(p<0.05)$ than that of controlbreads. BF addition increased the darkness and redness of the bread samples. While the lo west sensorial scores for flat breads were obtained with $30 \% \mathrm{LF}$ or $15 \% \mathrm{LF}+15 \% \mathrm{OF}$ addition, bazlama containing $30 \%$ OF or $10 \% \mathrm{LF}+10 \% \mathrm{BF}+10 \%$ OF and yufka containing $30 \%$ OF or $15 \% \mathrm{LF}+15 \% \mathrm{BF}$ or $10 \%$ $\mathrm{LF}+10 \% \mathrm{BF}+10 \% \mathrm{OF}$ appreciated with higher rates after control breads by panelists. Considering physical, chemical and sensory properties of flat breads, it can be concluded that $\mathrm{LF}, \mathrm{BF}$ and $\mathrm{OF}$ can be used at $10 \% \mathrm{LF}+10 \% \mathrm{BF}+10 \%$ OF levels success fully for both bazlama and yufka production.
\end{abstract}

Keywords Lupin, Buckwheat, Oat, Bazlama, Yufka

\section{Introduction}

Bread has a great importance in human nutrition as a protein and carbohydrate source. In Turkey, cereal based products especially bread has great importance in diets, $66 \%$ of the energy consumed per capita is supplied from cereals and $56 \%$ of this energy is supplied only from breads [1]. There are so many flat bread types all over the world known with different names such as chapatti, tortilla, tandoori, pita, baladi, taboon, lavash etc.[2]. Bazlama and yufka are the traditional flat bread types of Turkey. Bazlama is single layered, leavened, circular flat bread with creamy yellow color. It has average $3 \mathrm{~cm}$ thickness and diameters ranging from 10 to $20 \mathrm{~cm}[3]$. Yufka is single layered but unleavened bread with 1-2 $\mathrm{mm}$ thickness, $40-50 \mathrm{~cm}$ diameters and cream-color surface [4],[5] .

Lupin (Lupinus albus spp) as a valuable ancient legume contains comparatively higher amount of protein (about $40 \%$ by weight) than cereals and other legumes except soy.

* Corresponding author:

hacerlevent@hotmail.com(Hacer Levent)

Published online at http://journal.sapub.org/food

Copyright (C) 2012 Scientific \& Academic Publishing. All Rights Reserved
Lysine content of lupin proteins is high whereas methionine content is low.

When LF and wheat flour used together in food formulations, complementary effect is achieved due to the low lysine and high sulphur-containing amino acids (methionine and cysteine) content of wheat flour proteins [6]. Lup in is also rich in dietary fiber $(30-40 \%)$, fat (6-13\%), phytochemicals including antioxidants and phytosterols, vitamin and minerals [7-11].

Buckwheat (Fagopyrum esculentum Moench) is nutritious pseudocereal with its high biological value protein, dietary fiber, vitamins B1, B2 and E [12],[13]. It is also a good source of essential minerals (Fe, Mn, $\mathrm{Zn}$ and $\mathrm{Se}$ ), phytochemicals (especially rutin and quercetin) [13],[14]. It has anti- inflammatory and anticarcinogenic effects, controls the blood vessels and prevents haemorrhagic diseases and edema, reduces high blood pressure [15],[16],[17].

Oat is known with its high $\beta$-glucans content (2.2-7.8\%) which is soluble dietary fibre [18], B complex vitamins, protein, fat and minerals [19]. Cereal $\beta$-glukan usage, increase the functional quality of foods. It reduces the blood glucose, cholesterol and triglyceride level. It also protect humans against colon cancer [20],[21]. 
Considering nutritional and functional properties, lupin, buckwheat and oat flour has a high potential to be used in different foods.

In the literature, it has been reported that Turkish flat bread types enriched by barley flour and wheat bran [3],[4], triticale flour [22], resistant starch [5] and dairy by-products [23].

Due to the being of basic food in our diet, it is aimed to increase the nutritional and functional quality of flat breads by the incorporation of LF, BF and OF.

\section{Materials and Methods}

\subsection{Materials}

Buckwheat groats (without hull) were obtained from Yar Gida, Antalya, Turkey. Lupin (Lupinus albus L.) seeds were purchased from local market as traditionally debittered. Wheat flour, salt, sugar, fresh yeast and oat were purchased from local markets in Konya. Buckwheat, lupin seeds (after drying at $60{ }^{\circ} \mathrm{C}$ for $24 \mathrm{hr}$ ) and oat were ground in a hammer mill (Falling Number-3100 Laboratory Mill; Perten Instruments AB, Huddinge, Sweden) to obtain wholegrain flour.

\subsection{Methods}

\subsubsection{Bazlama and Yufka Preparation}

Flat bread samples were prepared according to Akbaş [24], Başman and Köksel [4] respectively by using the formulations in Table 1. LF, BF and OF were replaced with wheat flour at $30 \%, 15 \%+15 \%$ and $10 \%+10 \%+10 \%$ levels in both bazlama and yufka samples. All the ingredients were mixed in a Hobart mixer (Hobart N50, Canada Instruments, North York, Ontario, Canada) for optimum dough development.

For bazlama preparing, doughs were fermented for 1 hour at $30^{\circ} \mathrm{C}$ and divided into two equal pieces and shaped with hand like a ball and allowed to rest for 6 minutes at room conditions. After that, doughs were sheeted to final thickness of $10 \mathrm{~mm}$ by using stainless steel circle of $17 \mathrm{~cm}$ diameter and baked at $280 \pm 5^{\circ} \mathrm{C}$ on preheated sac for 5 minutes $(1500 \mathrm{~W})$.

For yufka samples, after mixing, doughs were allowed to rest at $30^{\circ} \mathrm{C}$ for half an hour and divided into four equal pieces, shaped like a ball, sheeted by hand rolling to the 1 $\mathrm{mm}$ thickness with the aid of their own flour. After sheeting, it was baked on preheated sac $280 \pm 5^{\circ} \mathrm{C}$ for $1 \mathrm{~min}$.

Baked bazlama and yufka samples were cooled at room temperature for 1 hour and after physical measurements and sensory evaluation, samples were stored in plastic bags for chemical analyses.

The color of flours and bread samples was evaluated by measuring the $\mathrm{L}^{*}, \mathrm{a}^{*}$ and $\mathrm{b}^{*}$ values using a Minolta CR-400 (Konica Minolta Sensing, Inc., Osaka, Japan). Saturation index $(\mathrm{SI})\left(\left(a^{\star 2}+b^{\star 2}\right)^{1 / 2}\right)$ of the samples were calcu lated.

\subsubsection{Chemical Analyses}

The samples were analyzed for their moisture, ash, crude protein using AACC standard methods [25].

The mineral ( $\mathrm{Ca}, \mathrm{Cu}, \mathrm{Fe}, \mathrm{Mg}, \mathrm{Mn}, \mathrm{P}, \mathrm{K}$ and $\mathrm{Zn}$ ) contents of the samples were determined by an Inductive coupled plasma atomic emission spectrometry (ICP-AES) (Vista series, Varian International A G, Zug, Switzerland) as given by Bubert and Hagenah [26].

\subsubsection{Sensory Analyses}

Bazlama and yufka samples were evaluated by 12 panelist who are familiar to flat breads. The sensory quality characteristics of bazlama (appearance, shape and symmetry, texture, mouthfeel, taste and odor, overall acceptability) and yufka samples (appearance, elasticity, mouthfeel, taste and odor, overall acceptability) were evaluated on a 1-9 scale where 1 represented "dislike extremely", 4-5 represented "acceptable" and 8-9 represented "like extremely".

\subsubsection{Statistical Analyses}

All data were subjected to analys is of variance (ANOVA) and Student's t comparison test. Statistical analyses were performed using the Statistical software JMP 5.0.1 (SAS Institute).

\section{Results and Discussion}

\subsection{Raw Material Properties}

The analyses results of flours used in the production of bazlama and yufka are presented in Table 2. The ash content of BF was significantly higher $(p<0.05)$ than that of other flours. LF had higher protein and mineral content (especially $\mathrm{Ca}, \mathrm{Cu}, \mathrm{Fe}, \mathrm{Mn}, \mathrm{P}$ and $\mathrm{Zn}$ ) according to $\mathrm{BF}$ and $\mathrm{OF}$. Also, BF was found to be a good source for $\mathrm{Mg}$ and $\mathrm{K}$ minerals. Literature knowledge confirmed our ash, protein and mineral analyses for different flours [6],[27],[28],[29].

As expected, BF gave the lowest $\mathrm{L}^{*}$ (lightness) and the highest $\mathrm{a}^{*}$ (redness) values. The highest $\mathrm{b}^{*}$ (yellowness) value was obtained with LF due to the natural seed characteristics. It is reported by Doxastakis et al. [27] that the yellow colors of the LF have a considerable appeal and would be a value in many foods.

\subsection{Pyhsical Properties of Bazlama and Yufka}

The diameter, thickness and spread ratio of flat breads are summarized in Table 3. The usage of LF, BF and OF or their blends did not significantly $(p>0.05)$ affected the diameters of bazlama samples, but decreased thickness and increased spread ratio. The lowest thickness and highest spread ratio values were obtained with LF supplemented bazlama samples.

Y1ld1z [30] reported that BF usage (0-30\%) in bazlama formulations did not significantly affected the diameter and thickness of the samples. In present study, usage of LF, BF 
and $\mathrm{OF}$ or their blends decreased the diameter and spread ratio of yufka samples. While $15 \% \mathrm{LF}+15 \%$ OF and $10 \%$ $\mathrm{LF}+10 \% \mathrm{BF}+10 \%$ OF gave higher diameter and spread

ratio after control samples, $15 \% \mathrm{LF}+15 \% \mathrm{BF}$ caused the highest decrement in these parameters in yufka samples.

Table 1. The Formulations of Flat Breads

\begin{tabular}{|c|c|c|c|c|c|c|c|c|c|c|c|c|c|c|c|c|}
\hline $\begin{array}{l}\text { Ingredient } \\
(\mathrm{g})\end{array}$ & $\begin{array}{l}\text { Control } \\
\text { Bazlama }\end{array}$ & $\begin{array}{l}\text { Control } \\
\text { Yufka }\end{array}$ & \multicolumn{7}{|c|}{ Bazlama Containing LF/BF/OF } & \multicolumn{7}{|c|}{ Yufka Containing LF/BF/OF } \\
\hline & & & & & & & & & & & & & & & & \\
\hline Wheat liour & 200 & 200 & 140 & 140 & 140 & 140 & 140 & 140 & 140 & 140 & & 140 & 140 & 140 & 140 & 140 \\
\hline Salt & 3 & 3 & 3 & 3 & 3 & 3 & 3 & 3 & 3 & 3 & 3 & 3 & 3 & 3 & 3 & 3 \\
\hline Sugar & 2 & 0 & 2 & 2 & 2 & 2 & 2 & 2 & 2 & 0 & 0 & 0 & 0 & 0 & 0 & 0 \\
\hline Fresh yeast & 5 & 0 & 5 & 5 & 5 & 5 & 5 & 5 & 5 & 0 & 0 & 0 & 0 & 0 & 0 & 0 \\
\hline LF & 0 & 0 & 60 & 0 & 0 & 30 & 0 & 30 & 20 & 60 & 0 & 0 & 30 & 0 & 30 & 20 \\
\hline $\mathrm{BF}$ & 0 & 0 & 0 & 60 & 0 & 30 & 30 & 0 & 20 & 0 & 60 & 0 & 30 & 30 & 0 & 20 \\
\hline OF & 0 & 0 & 0 & 0 & 60 & 0 & 30 & 30 & 20 & 0 & 0 & 60 & 0 & 30 & 30 & 20 \\
\hline
\end{tabular}

LF:Lupin flour, BF:Buckwheat flour, OF:Oat flour

Table 2. Chemical Analysis (dry-weight basis) and Color Values of Flours

\begin{tabular}{|c|c|c|c|c|}
\hline & Wheat Flour & Lupin Flour & Buckwheat Flour & Oat Flour \\
\hline Moisture(\%) & $11.08 \pm 0.24^{\mathrm{a}}$ & $9.31 \pm 0.43^{b}$ & $9.41 \pm 0.32^{b}$ & $5.03 \pm 0.22^{\mathrm{c}}$ \\
\hline Ash $(\%)$ & $0.47 \pm 0.03^{\mathrm{d}}$ & $1.51 \pm 0.02^{\mathrm{c}}$ & $1.84 \pm 0.01^{\mathrm{a}}$ & $1.74 \pm 0.02^{\mathrm{b}}$ \\
\hline $\operatorname{Protein}(\%)$ & $11.67 \pm 0.12^{\mathrm{c}}$ & $38.75 \pm 0.14^{\mathrm{a}}$ & $12.18 \pm 0.25^{\mathrm{c}}$ & $13.35 \pm 0.24^{\mathrm{b}}$ \\
\hline \multicolumn{5}{|c|}{ Minerals (mg/lo0g) } \\
\hline $\mathrm{Ca}$ & $24.0 \pm 0.84^{\mathrm{c}}$ & $385.81 \pm 1.42^{\mathrm{a}}$ & $21.82 \pm 1.15^{\mathrm{c}}$ & $39.18 \pm 0.96^{\mathrm{b}}$ \\
\hline $\mathrm{Cu}$ & $0.28 \pm 0.08^{\mathrm{b}}$ & $1.82 \pm 0.09^{\mathrm{a}}$ & $0.35 \pm 0.05^{\mathrm{b}}$ & $0.41 \pm 0.04^{\mathrm{b}}$ \\
\hline $\mathrm{Fe}$ & $1.21 \pm 0,62^{\mathrm{b}}$ & $4.21 \pm 0.65^{\mathrm{a}}$ & $2.65 \pm 0.91^{\mathrm{ab}}$ & $4.02 \pm 0.39^{\mathrm{a}}$ \\
\hline $\mathrm{Mg}$ & $42.40 \pm 1.69^{\mathrm{d}}$ & $98.32 \pm 1.87^{\mathrm{c}}$ & $241.61 \pm 1.57^{\mathrm{a}}$ & $137.11 \pm 1.85^{\mathrm{b}}$ \\
\hline $\mathrm{Mn}$ & $0.42 \pm 0.04^{\mathrm{c}}$ & $151.15 \pm 0.09^{\mathrm{a}}$ & $0.30 \pm 0.07^{\mathrm{c}}$ & $0.64 \pm 0.08^{\mathrm{b}}$ \\
\hline $\mathrm{P}$ & $132.61 \pm 2.27^{\mathrm{d}}$ & $622.83 \pm 1.88^{\mathrm{a}}$ & $442.76 \pm 1.92^{\mathrm{b}}$ & $321.82 \pm 2.43^{\mathrm{c}}$ \\
\hline $\mathrm{K}$ & $138.24 \pm 1.75^{\mathrm{c}}$ & $57.55 \pm 1.90^{\mathrm{d}}$ & $412.23 \pm 1.31^{\mathrm{a}}$ & $295.30 \pm 1.55^{\mathrm{b}}$ \\
\hline $\mathrm{Zn}$ & $0.92 \pm 0.09^{c}$ & $5.48 \pm 0.11^{\mathrm{a}}$ & $2.15 \pm 0.14^{\mathrm{b}}$ & $2.42 \pm 0.12^{\mathrm{b}}$ \\
\hline \multicolumn{5}{|l|}{ Colorvalues } \\
\hline$L^{*}$ & $95.68 \pm 0.22^{\mathrm{a}}$ & $89.12 \pm 0.17^{\mathrm{c}}$ & $67.75 \pm 0.35^{\mathrm{d}}$ & $90.58 \pm 0.39^{\mathrm{b}}$ \\
\hline$a^{*}$ & $-0.87 \pm 0.16^{\mathrm{c}}$ & $-0.95 \pm 0.14^{\mathrm{c}}$ & $3.52 \pm 0.15^{\mathrm{a}}$ & $-0.35 \pm 0.12^{\mathrm{b}}$ \\
\hline$b^{*}$ & $9.85 \pm 0.15^{\mathrm{d}}$ & $32.54 \pm 0.33^{\mathrm{a}}$ & $16.62 \pm 0.28^{\mathrm{b}}$ & $13.56 \pm 0.19^{c}$ \\
\hline$S I$ & $9.88 \pm 0.18^{\mathrm{d}}$ & $32.50 \pm 0.41^{\mathrm{a}}$ & $16.99 \pm 0.31^{\mathrm{b}}$ & $13.56 \pm 0.20^{\mathrm{c}}$ \\
\hline
\end{tabular}

* Means $( \pm$ standard error) with same letter within raw are not significantly different $(p<0.05)$

Table 3. SomePhysicalProperties of Bazlama and Yufka Samples*

\begin{tabular}{|c|c|c|c|}
\hline & Diameter (mm) & $\begin{array}{l}\text { Thickness } \\
(\mathrm{mm})\end{array}$ & Spread ratio $(\mathrm{D} / \mathrm{T})$ \\
\hline \multicolumn{4}{|l|}{ Bazlama } \\
\hline Control & $16.7 \pm 0.42^{\mathrm{a}}$ & $1.34 \pm 0.04^{\mathrm{a}}$ & $12.6 \pm 0.15^{\mathrm{d}}$ \\
\hline $30 \% \mathrm{LF}$ & $16.5 \pm 0.56^{\mathrm{a}}$ & $0.94 \pm 0.03^{\mathrm{c}}$ & $17.5 \pm 0.10^{\mathrm{a}}$ \\
\hline $30 \% \mathrm{BF}$ & $16.5 \pm 0.42^{\mathrm{a}}$ & $1.02 \pm 0.03^{\mathrm{bc}}$ & $16.2 \pm 0.25^{\mathrm{bc}}$ \\
\hline $30 \% \mathrm{OF}$ & $16.3 \pm 0.28^{\mathrm{a}}$ & $1.04 \pm 0.05^{\mathrm{b}}$ & $15.7 \pm 0.24^{\mathrm{c}}$ \\
\hline $15 \% \mathrm{LF}+15 \% \mathrm{BF}$ & $16.5 \pm 0.42^{\mathrm{a}}$ & $0.96 \pm 0.04^{\mathrm{bc}}$ & $17.2 \pm 0.26^{\mathrm{a}}$ \\
\hline $15 \% \mathrm{BF}+15 \% \mathrm{OF}$ & $16.3 \pm 0.42^{\mathrm{a}}$ & $0.99 \pm 0.01^{\mathrm{bc}}$ & $16.5 \pm 0.37^{b}$ \\
\hline $15 \% \mathrm{LF}+15 \% \mathrm{OF}$ & $16.6 \pm 0.56^{\mathrm{a}}$ & $0.97 \pm 0.03^{\mathrm{bc}}$ & $17.1 \pm 0.16^{\mathrm{a}}$ \\
\hline $10 \% \mathrm{LF}+10 \% \mathrm{BF}+10 \% \mathrm{OF}$ & $16.6 \pm 0.39^{\mathrm{a}}$ & $0.97 \pm 0.04^{\mathrm{bc}}$ & $17.1 \pm 0.23^{\mathrm{a}}$ \\
\hline \multicolumn{4}{|l|}{ Yufka } \\
\hline Control & $31.6 \pm 0.45^{\mathrm{a}}$ & $0.14 \pm 0.01^{\mathrm{a}}$ & $225.4 \pm 0.43^{\mathrm{a}}$ \\
\hline $30 \% \mathrm{LF}$ & $27.9 \pm 0.21^{\mathrm{e}}$ & $0.17 \pm 0.04^{\mathrm{a}}$ & $164.4 \pm 0.24^{\mathrm{f}}$ \\
\hline $30 \% \mathrm{BF}$ & $28.7 \pm 0.39^{\mathrm{cd}}$ & $0.16 \pm 0.03^{\mathrm{a}}$ & $179.5 \pm 0.30^{\mathrm{d}}$ \\
\hline $30 \% \mathrm{OF}$ & $29.3 \pm 0.11^{\mathrm{bc}}$ & $0.16 \pm 0.04^{\mathrm{a}}$ & $181.4 \pm 0.33^{\mathrm{c}}$ \\
\hline $15 \% \mathrm{LF}+15 \% \mathrm{BF}$ & $27.6 \pm 0.29^{\mathrm{e}}$ & $0.17 \pm 0.02^{\mathrm{a}}$ & $162.1 \pm 0.17^{\mathrm{g}}$ \\
\hline $15 \% \mathrm{BF}+15 \% \mathrm{OF}$ & $28.1 \pm 0.16^{\mathrm{de}}$ & $0.16 \pm 0.05^{\mathrm{a}}$ & $175.7 \pm 0.18^{\mathrm{e}}$ \\
\hline $15 \% \mathrm{LF}+15 \% \mathrm{OF}$ & $29.6 \pm 0.14^{b}$ & $0.15 \pm 0.03^{\mathrm{a}}$ & $197.4 \pm 0.51^{\mathrm{b}}$ \\
\hline $10 \% \mathrm{LF}+10 \% \mathrm{BF}+10 \% \mathrm{OF}$ & $29.6 \pm 0.32^{b}$ & $0.15 \pm 0.04^{\mathrm{a}}$ & $197.1 \pm 0.38^{\mathrm{b}}$ \\
\hline
\end{tabular}

*Means( \pm stand ard error) $\quad$ with same letter within column are not significantly different $(\mathrm{p}<0.05)$. LF:Lupin flour, BF:Buckwheat flour, OF:Oat flour, $\mathrm{D} / \mathrm{T}$ :Diameter/Thickness 


\subsection{Che mical Compositions of B azlama and Yufka}

Chemical compositions of flat bread samples are given in Table 4. The moisture content of bazlama and yufka samples with $15 \% \mathrm{BF}+\% 15 \mathrm{OF}$ and $15 \% \mathrm{LF}+15 \% \mathrm{OF}$ were not found significantly different $(\mathrm{p}>0.05)$ compared to control.

The usage of $\mathrm{BF}$ at $30 \%$ level increased the ash content of bazlama and yufka samples from $1.25 \%$ and $1.20 \%$ to $1.71 \%$ and $1.65 \%$, respectively. In the literature, it is reported that the ash content of spaghetti and tarhana increased with the addition of $\mathrm{BF}$ due to the rich ash content of BF [6],[29]. Protein contents of bazlama and yufka samples were found between $11.85 \%$ and $19.97 \% ; 11.62 \%$ and $19.74 \%$, respectively. The highest protein value was obtained with the addition of LF in both bazlama and yufka samples. Jayasena et al. [31] reported that there was $42 \%$ increment in protein content of instant noodles by replacing only $20 \%$ wheat flour with LF. A lso Ballester et al. [32] found the increment in protein content of the cookies up to $55.7 \%$ with LF (5-25\%) addition.

\subsection{Miner al Compositions of Bazlama and Yufka}

Mineral contents of bazlama and yufka samples are given in Table 5. The rich mineral content of LF, BF and OF caused to increase in mineral content of flat breads. The increments in bazlama and yufka samples with 30\% LF supplementation were found as 2.5 and 3.77 times in $\mathrm{Ca}$, 2.0 and 3.2 times in $\mathrm{Cu}, 1.73$ and 2.38 times in $\mathrm{Fe}, 30.5$ and 31.5 times in $\mathrm{Mn}, 2.0$ and 2.27 times in P, 2.34 and 2.84 times in $\mathrm{Zn}$ according to control samples respectively. BF addition (at 30\% level) increased the $\mathrm{Mg}$ and $\mathrm{P}$ contents $(\mathrm{mg} / 100 \mathrm{~g})$ of bazlama and yufka samples from 31.36 and 30.64 to 84.05 and 85.64 , respectively.

It is reported that the lupin enriched pasta samples showed higher amounts of protein, $\mathrm{Ca}, \mathrm{P}, \mathrm{Mg}$ and $\mathrm{Zn}$ content than control pasta [33]. Bilgiçli [29] found increments in the mineral contents (especially $\mathrm{K}, \mathrm{Mg}$ and $\mathrm{P}$ ) of tarhana samples with the addition of BF. In the study conducted by Tamime et al. [34] Mn, P and Mg content of Kishk samples made from oat varieties were found higher than that of barley and wheat. In another study, it is reported that $\mathrm{K}, \mathrm{Ca}$ and $\mathrm{Fe}$ contents of couscous prepared with oat flour were higher than that of traditional couscous and couscous with eggs [35].

\subsection{Color values of bazlama and yufka}

Color values of samples are presented in Table 6. Raw material colors directly a ffected the color of flat breads. The lowest $\mathrm{L}^{*}$ values were observed in $30 \% \mathrm{BF}$ and $15 \%$ $\mathrm{BF}+15 \%$ OF bazlama and yufka samples. Bilg içli [29] and Lin et al. [36] reported that BF enriched tarhana and bread had lower $\mathrm{L}$ and higher $\mathrm{a}$ and $\mathrm{b}$ values than that of control products. The natural dark pig mentation of whole $\mathrm{BF}$ and the tendency of BF on Maillard reaction could be effective on this color change [37]. The usage of LF increased the b*(yellowness) values of bazlama and yufka samples at all addition levels. Similarly, it was reported that the crumb colors of breads prepared with LF became more yellowish [27]. Generally $b^{*}$ and SI values showed same tendency, the highest SI values were found in LF at 30\% levels.

\subsection{Sensory Properties of Bazlama and Yufka Samples}

The sensory scores of bazlama and yufka samples are presented in Table 7 and 8. Enriched bazlama samples prepared with the addition of OF at $30 \%$ level and blends of $\mathrm{LF}, \mathrm{BF}$ and $\mathrm{OF}$ at equal ratios $(10 \%)$ were scored higher for their appearance, shape and symmetry, texture, taste and odor after control bread. Yu fka samp les produced with $30 \%$ OF or $15 \% \mathrm{LF}+15 \% \mathrm{BF}$ or the blends of LF, BF and OF at equal ratios (10\%) gave high overall acceptability scores. Supplementation of breads with $30 \%$ LF or $15 \%$ LF $+15 \%$ OF gave the lowest sensory attributes in flat breads. The highest decrement on taste and odor scores of bazlama and yufka samples was found at $15 \% \mathrm{LF}+15 \% \mathrm{OF}$ and $30 \% \mathrm{BF}$ addition respectively.

Table 4. Results of Some Chemical Analysis of Bazlama and Yufka Samples*

\begin{tabular}{|c|c|c|c|}
\hline & Moisture & $\mathrm{Ash}^{* *}$ & Protein** \\
\hline \multicolumn{4}{|l|}{ Bazlama } \\
\hline Control & $31.80 \pm 0.49^{\mathrm{c}}$ & $1.25 \pm 0.03^{\mathrm{d}}$ & $11.85 \pm 0.12^{\mathrm{e}}$ \\
\hline $30 \% \mathrm{LF}$ & $34.14 \pm 0.20^{\mathrm{a}}$ & $1.55 \pm 0.04^{\mathrm{c}}$ & $19.97 \pm 0.11^{\mathrm{a}}$ \\
\hline $30 \% \mathrm{BF}$ & $34.62 \pm 0.48^{\mathrm{a}}$ & $1.71 \pm 0.01^{\mathrm{a}}$ & $12.01 \pm 0.08^{\mathrm{de}}$ \\
\hline $30 \% \mathrm{OF}$ & $32.74 \pm 0.13^{\mathrm{b}}$ & $1.63 \pm 0.04^{\mathrm{b}}$ & $12.23 \pm 0.09^{\mathrm{d}}$ \\
\hline $15 \% \mathrm{LF}+15 \% \mathrm{BF}$ & $34.80 \pm 0.25^{\mathrm{a}}$ & $1.62 \pm 0.03^{\mathrm{b}}$ & $15.98 \pm 0.08^{\mathrm{b}}$ \\
\hline $15 \% \mathrm{BF}+15 \% \mathrm{OF}$ & $32.12 \pm 0.16^{\mathrm{bc}}$ & $1.65 \pm 0.01^{\mathrm{ab}}$ & $12.18 \pm 0.10^{\mathrm{d}}$ \\
\hline $15 \% \mathrm{LF}+15 \% \mathrm{OF}$ & $32.30 \pm 0.42^{\mathrm{bc}}$ & $1.59 \pm 0.03^{\mathrm{bc}}$ & $16.18 \pm 0.11^{\mathrm{b}}$ \\
\hline $10 \% \mathrm{LF}+10 \% \mathrm{BF}+10 \% \mathrm{OF}$ & $32.90 \pm 0.38^{\mathrm{b}}$ & $1.61 \pm 0.01^{\mathrm{bc}}$ & $14.75 \pm 0.10^{\mathrm{c}}$ \\
\hline \multicolumn{4}{|l|}{ Yufka } \\
\hline Control & $6.82 \pm 0.38^{\mathrm{d}}$ & $1.20 \pm 0.07^{\mathrm{c}}$ & $11.62 \pm 0.15^{\mathrm{e}}$ \\
\hline $30 \%$ LF & $7.52 \pm 0.21^{\mathrm{bc}}$ & $1.50 \pm 0.05^{\mathrm{b}}$ & $19.74 \pm 0.12^{\mathrm{a}}$ \\
\hline $30 \% \mathrm{BF}$ & $7.85 \pm 0.32^{\mathrm{b}}$ & $1.65 \pm 0.01^{\mathrm{a}}$ & $11.76 \pm 0.15^{\mathrm{de}}$ \\
\hline $30 \%$ OF & $9.28 \pm 0.12^{\mathrm{a}}$ & $1.56 \pm 0.03^{\mathrm{ab}}$ & $11.98 \pm 0.14^{\mathrm{d}}$ \\
\hline $15 \% \mathrm{LF}+15 \% \mathrm{BF}$ & $9.53 \pm 0.19^{\mathrm{a}}$ & $1.56 \pm 0.03^{\mathrm{ab}}$ & $15.75 \pm 0.18^{\mathrm{b}}$ \\
\hline $15 \% \mathrm{BF}+15 \% \mathrm{OF}$ & $7.18 \pm 0.14^{\mathrm{cd}}$ & $1.58 \pm 0.04^{\mathrm{ab}}$ & $11.94 \pm 0.11^{\mathrm{de}}$ \\
\hline $15 \% \mathrm{LF}+15 \% \mathrm{OF}$ & $7.24^{\mathrm{c}} \pm 0.15^{\mathrm{d}}$ & $1.51 \pm 0.01^{\mathrm{b}}$ & $15.93 \pm 0.12^{\mathrm{b}}$ \\
\hline $10 \% \mathrm{LF}+10 \% \mathrm{BF}+10 \% \mathrm{OF}$ & $7.47 \pm 0.25^{\mathrm{bc}}$ & $1.52 \pm 0.04^{\mathrm{b}}$ & $14.51 \pm 0.16^{\mathrm{c}}$ \\
\hline
\end{tabular}

* Means ( \pm standard error $) \quad$ with same letter within column are not significantly different $(\mathrm{p}<0.05)$. **Ash, protein and fat values are based on dry matter. LF:Lupin flour, BF:Buckwheat flour, OF:Oat flour 
Table 5. Mineral Contents of Bazlama and Yufka Samples (mg/100g dry-weight basis)

\begin{tabular}{|c|c|c|c|c|c|c|c|c|}
\hline & $\mathrm{Ca}$ & $\mathrm{Cu}$ & $\mathrm{Fe}$ & $\mathrm{Mg}$ & $\mathrm{Mn}$ & $\mathrm{P}$ & $\mathrm{K}$ & $\mathrm{Zn}$ \\
\hline \multicolumn{9}{|l|}{ Bazlama } \\
\hline Control & $30.86 \pm 0.86^{\mathrm{e}}$ & $0.22 \pm 0.06^{\mathrm{c}}$ & $0.99 \pm 0.17^{\mathrm{d}}$ & $31.36 \pm 0.72^{\mathrm{g}}$ & $0.66 \pm 0.05^{\mathrm{h}}$ & $74.18 \pm 1.21^{\mathrm{f}}$ & $163.36 \pm 1.57^{\mathrm{f}}$ & $0.58 \pm 0.04^{\mathrm{d}}$ \\
\hline $30 \%$ LF & $77.39 \pm 0.70^{\mathrm{a}}$ & $0.45 \pm 0.03^{\mathrm{a}}$ & $1.71 \pm 0.10^{\mathrm{a}}$ & $45.65 \pm 0.92^{\mathrm{f}}$ & $20.16 \pm 0.04^{\mathrm{a}}$ & $149.72 \pm 2.08^{\mathrm{a}}$ & $122.59 \pm 0.83^{\mathrm{g}}$ & $1.36 \pm 0.07^{\mathrm{a}}$ \\
\hline $30 \% \mathrm{BF}$ & $23.17 \pm 0.63^{\mathrm{g}}$ & $0.25 \pm 0.04^{\mathrm{c}}$ & $1.14 \pm 0.19^{\mathrm{cd}}$ & $84.05 \pm 0.85^{\mathrm{a}}$ & $0.85 \pm 0.01^{\mathrm{g}}$ & $129.80 \pm 1.13^{\mathrm{c}}$ & $229.78 \pm 1.10^{\mathrm{a}}$ & $0.85 \pm 0.26^{\text {bod }}$ \\
\hline $30 \%$ OF & $29.76 \pm 0.79^{\mathrm{e}}$ & $0.31 \pm 0.01^{\mathrm{bc}}$ & $1.42 \pm 0.28^{\mathrm{abc}}$ & $63.39 \pm 1.14^{\mathrm{d}}$ & $1.46 \pm 0.03^{\mathrm{e}}$ & $118.30 \pm 1.48^{\mathrm{e}}$ & $218.40 \pm 1.98^{\mathrm{b}}$ & $1.18 \pm 0.18^{\mathrm{a}}$ \\
\hline $15 \% \mathrm{LF}+15 \% \mathrm{BF}$ & $49.34 \pm 0.66^{\mathrm{c}}$ & $0.25 \pm 0.04^{\mathrm{c}}$ & $1.56 \pm 0.20^{\mathrm{ab}}$ & $67.75 \pm 1.06^{\mathrm{c}}$ & $10.17 \pm 0.06^{\mathrm{c}}$ & $137.60 \pm 1.53^{\mathrm{b}}$ & $176.58 \pm 1.44^{\mathrm{d}}$ & $1.07 \pm 0.13^{\mathrm{abc}}$ \\
\hline $15 \% \mathrm{BF}+15 \% \mathrm{OF}$ & $25.15 \pm 0.56^{\mathrm{f}}$ & $0.23 \pm 0.06^{\mathrm{c}}$ & $1.24 \pm 0.18^{\mathrm{bad}}$ & $77.47 \pm 1.23^{\mathrm{b}}$ & $1.15 \pm 0.04^{\mathrm{f}}$ & $124.50 \pm 0.89^{\mathrm{d}}$ & $232.32 \pm 0.95^{\mathrm{a}}$ & $0.77 \pm 0.08^{\mathrm{cd}}$ \\
\hline $15 \% \mathrm{LF}+15 \% \mathrm{OF}$ & $51.11 \pm 0.89^{\mathrm{b}}$ & $0.35 \pm 0.04^{\mathrm{b}}$ & $1.65 \pm 0.17^{\mathrm{ab}}$ & $56.44 \pm 0.95^{\mathrm{e}}$ & $10.58 \pm 0.07^{\mathrm{b}}$ & $127.15 \pm 1.40^{\mathrm{dd}}$ & $168.80 \pm 1.13^{\mathrm{e}}$ & $1.28 \pm 0.10^{\mathrm{a}}$ \\
\hline $10 \% \mathrm{LF}+10 \% \mathrm{BF}+10 \% \mathrm{OF}$ & $41.39 \pm 0.55^{\mathrm{d}}$ & $0.25 \pm 0.01^{\mathrm{c}}$ & $1.45 \pm 0.11^{\mathrm{abc}}$ & $67.93 \pm 0.96^{\mathrm{c}}$ & $7.49 \pm 0.03^{\mathrm{d}}$ & $128.16 \pm 0.99^{\mathrm{c}}$ & $197.91 \pm 0.87^{\mathrm{c}}$ & $1.11 \pm 0.15^{\mathrm{ab}}$ \\
\hline \multicolumn{9}{|c|}{ Yufka } \\
\hline Control & $20.61 \pm 0.65^{\mathrm{f}}$ & $0.15 \pm 0.03^{\mathrm{c}}$ & $0.73 \pm 0.20^{\mathrm{c}}$ & $30.64 \pm 0.65^{\mathrm{g}}$ & $0.64 \pm 0.03^{\mathrm{h}}$ & $68.74 \pm 1.04^{\mathrm{f}}$ & $148.83 \pm 1.17^{\mathrm{f}}$ & $0.46 \pm 0.12^{\mathrm{d}}$ \\
\hline $30 \% \mathrm{LF}$ & $77.78 \pm 0.74^{\mathrm{a}}$ & $0.48 \pm 0.01^{\mathrm{a}}$ & $1.74 \pm 0.14^{\mathrm{a}}$ & $44.63 \pm 1.23^{\mathrm{f}}$ & $20.18 \pm 0.06^{\mathrm{a}}$ & $155.80 \pm 1.13^{\mathrm{a}}$ & $112.76 \pm 1.71^{\mathrm{g}}$ & $1.31 \pm 0.06^{\mathrm{a}}$ \\
\hline $30 \% \mathrm{BF}$ & $22.09 \pm 0.50^{\mathrm{f}}$ & $0.23 \pm 0.05^{\mathrm{bc}}$ & $1.19 \pm 0.27^{\mathrm{b}}$ & $85.64 \pm 0.91^{\mathrm{a}}$ & $0.87 \pm 0.04^{\mathrm{g}}$ & $138.40 \pm 1.20^{\mathrm{b}}$ & $226.40 \pm 1.98^{\mathrm{a}}$ & $0.82 \pm 0.22^{\mathrm{cd}}$ \\
\hline $30 \% \mathrm{OF}$ & $28.65 \pm 0.77^{\mathrm{d}}$ & $0.28 \pm 0.04^{\mathrm{b}}$ & $1.45 \pm 0.18^{\mathrm{ab}}$ & $65.40 \pm 0.77^{\mathrm{d}}$ & $1.57 \pm 0.05^{\mathrm{e}}$ & $126.30 \pm 1.68^{\mathrm{d}}$ & $212.13 \pm 0.96^{\mathrm{b}}$ & $1.06 \pm 0.08^{\mathrm{abc}}$ \\
\hline $15 \% \mathrm{LF}+15 \% \mathrm{BF}$ & $50.83 \pm 0.82^{\mathrm{b}}$ & $0.27 \pm 0.07^{\mathrm{b}}$ & $1.52 \pm 0.14^{\mathrm{ab}}$ & $68.36 \pm 0.93^{\mathrm{c}}$ & $10.00 \pm 0.06^{\mathrm{c}}$ & $135.48 \pm 2.02^{\mathrm{bc}}$ & $182.13 \pm 1.60^{\mathrm{d}}$ & $1.12 \pm 0.20^{\mathrm{abc}}$ \\
\hline $15 \% \mathrm{BF}+15 \% \mathrm{OF}$ & $24.70 \pm 0.70^{\mathrm{e}}$ & $0.24 \pm 0.06^{\mathrm{bc}}$ & $1.22 \pm 0.16^{\mathrm{b}}$ & $76.07 \pm 0.76^{\mathrm{b}}$ & $1.13 \pm 0.07^{\mathrm{f}}$ & $122.16 \pm 1.33^{\mathrm{e}}$ & $214.24 \pm 0.82^{\mathrm{b}}$ & $0.88 \pm 0.25^{\mathrm{bc}}$ \\
\hline $15 \% \mathrm{LF}+15 \% \mathrm{OF}$ & $52.30 \pm 0.42^{\mathrm{b}}$ & $0.32 \pm 0.01^{\mathrm{b}}$ & $1.59 \pm 0.13^{\mathrm{ab}}$ & $54.13 \pm 1.01^{\mathrm{e}}$ & $10.46 \pm 0.05^{\mathrm{b}}$ & $129.15 \pm 0.99^{\mathrm{d}}$ & $165.76 \pm 1.07^{\mathrm{e}}$ & $1.26 \pm 0.13^{\mathrm{ab}}$ \\
\hline $10 \% \mathrm{LF}+10 \% \mathrm{BF}+10 \% \mathrm{OF}$ & $41.38 \pm 0.53^{\mathrm{c}}$ & $0.26 \pm 0.05^{\mathrm{b}}$ & $1.49 \pm 0.16^{\mathrm{ab}}$ & $64.30 \pm 0.88^{\mathrm{d}}$ & $7.01 \pm 0.01^{\mathrm{d}}$ & $132.89 \pm 1.25^{\mathrm{c}}$ & $186.60 \pm 0.85^{\mathrm{c}}$ & $0.97 \pm 0.19^{\mathrm{abc}}$ \\
\hline
\end{tabular}

Means( \pm standard error) $\quad$ with same letter within column are not significantly different $(\mathrm{p}<0.05)$. LF:Lupin flour, BF:Buckwheat flour, OF:Oat flour

Table 6. Color Values of Bread Samples*

\begin{tabular}{|c|c|c|c|c|}
\hline & $\mathrm{L}^{*}$ & $a^{*}$ & $b^{*}$ & SI \\
\hline \multicolumn{5}{|l|}{ Bazlama } \\
\hline Control & $77.97 \pm 0.66^{\mathrm{a}}$ & $-0.73 \pm 0.11^{\mathrm{f}}$ & $17.27 \pm 0.24^{\mathrm{f}}$ & $17.29 \pm 0.24^{\mathrm{f}}$ \\
\hline $30 \%$ LF & $71.00 \pm 0.49^{\mathrm{d}}$ & $-0,84 \pm 0.12^{\mathrm{f}}$ & $38.25 \pm 0.35^{\mathrm{a}}$ & $38.26 \pm 0.35^{\mathrm{a}}$ \\
\hline $30 \% \mathrm{BF}$ & $65.50 \pm 0.56^{\mathrm{f}}$ & $5.79 \pm 0.55^{\mathrm{a}}$ & $18.37 \pm 0.17^{\mathrm{e}}$ & $19.26 \pm 0.32^{\mathrm{e}}$ \\
\hline $30 \%$ OF & $74.38 \pm 0.39^{b}$ & $1.68 \pm 0.15^{\mathrm{d}}$ & $17.31 \pm 0.14^{\mathrm{f}}$ & $17.39 \pm 0.16^{\mathrm{f}}$ \\
\hline $15 \% \mathrm{LF}+15 \% \mathrm{BF}$ & $67.40 \pm 0.14^{\mathrm{e}}$ & $3.56 \pm 0.19^{\mathrm{b}}$ & $28.25 \pm 0.21^{\mathrm{b}}$ & $28.47 \pm 0.23^{\mathrm{b}}$ \\
\hline $15 \% \mathrm{BF}+15 \% \mathrm{OF}$ & $66.21 \pm 0.29^{\mathrm{f}}$ & $5.37 \pm 0.22^{\mathrm{a}}$ & $21.34 \pm 0.19^{\mathrm{d}}$ & $22.01 \pm 0.24^{\mathrm{d}}$ \\
\hline $15 \% \mathrm{LF}+15 \% \mathrm{OF}$ & $72.20 \pm 0.28^{\mathrm{c}}$ & $0.21 \pm 0.15^{\mathrm{e}}$ & $27.45 \pm 0.21^{\mathrm{c}}$ & $27.45 \pm 0.21^{\mathrm{c}}$ \\
\hline $10 \% \mathrm{LF}+10 \% \mathrm{BF}+10 \% \mathrm{OF}$ & $68.17 \pm 0.24^{\mathrm{e}}$ & $2.87 \pm 0.18^{\mathrm{c}}$ & $27.38 \pm 0.28^{\mathrm{c}}$ & $27.53 \pm 0.30^{\mathrm{c}}$ \\
\hline \multicolumn{5}{|l|}{ Yufka } \\
\hline Control & $78.85 \pm 0.77^{\mathrm{a}}$ & $-0.19 \pm 0.11^{\mathrm{d}}$ & $16.95 \pm 0.21^{\mathrm{f}}$ & $16.95 \pm 0.21^{\mathrm{g}}$ \\
\hline $30 \% \mathrm{LF}$ & $72.74 \pm 0.50^{\mathrm{c}}$ & $0,21 \pm 0.12^{\mathrm{cd}}$ & $34.61 \pm 0.86^{\mathrm{a}}$ & $34.61 \pm 0.86^{\mathrm{a}}$ \\
\hline $30 \% \mathrm{BF}$ & $68.21 \pm 0.86^{\mathrm{e}}$ & $5.65 \pm 0.49^{\mathrm{a}}$ & $19.45 \pm 0.64^{\mathrm{e}}$ & $20.25 \pm 0.74^{\mathrm{e}}$ \\
\hline $30 \%$ OF & $76.72 \pm 1.01^{\mathrm{b}}$ & $1.68 \pm 0.14^{\mathrm{b}}$ & $18.79 \pm 0.57^{\mathrm{e}}$ & $18.86 \pm 0.59^{\mathrm{f}}$ \\
\hline $15 \% \mathrm{LF}+15 \% \mathrm{BF}$ & $70.12 \pm 0.59^{\mathrm{d}}$ & $1.51 \pm 0.18^{\mathrm{b}}$ & $28.25 \pm 0.35^{\mathrm{b}}$ & $28.29 \pm 0.36^{\mathrm{b}}$ \\
\hline $15 \% \mathrm{BF}+15 \% \mathrm{OF}$ & $69.01 \pm 0.70^{\mathrm{de}}$ & $5.37 \pm 0.12^{\mathrm{a}}$ & $22.29 \pm 0.41^{\mathrm{d}}$ & $22.92 \pm 0.42^{\mathrm{d}}$ \\
\hline $15 \% \mathrm{LF}+15 \% \mathrm{OF}$ & $75.25 \pm 0.56^{\mathrm{b}}$ & $0.58 \pm 0.22^{\mathrm{c}}$ & $27.45 \pm 0.18^{\mathrm{b}}$ & $27.45 \pm 0.18^{\mathrm{b}}$ \\
\hline $10 \% \mathrm{LF}+10 \% \mathrm{BF}+10 \% \mathrm{OF}$ & $70.65 \pm 0.91^{\mathrm{d}}$ & $1.45 \pm 0.16^{\mathrm{b}}$ & $24.47 \pm 0.66^{\mathrm{c}}$ & $24.51 \pm 0.67^{\mathrm{c}}$ \\
\hline
\end{tabular}

*Means $( \pm$ stand ard error) with same letter within column are not significantly different $(\mathrm{p}<0.05)$. Lupin flour, BF:Buckwheat flour, OF:Oat flour

Table 7. Results of Sensory Analysis of Bazlama Samples*

\begin{tabular}{|c|c|c|c|c|c|c|}
\hline & Appearance & $\begin{array}{l}\text { Shape and } \\
\text { symmetry }\end{array}$ & Texture & Mouthfeel & $\begin{array}{l}\text { Taste and } \\
\text { Odor }\end{array}$ & $\begin{array}{c}\text { Overall } \\
\text { acceptability }\end{array}$ \\
\hline Control & $8.5 \pm 0.70^{\mathrm{a}}$ & $8.8 \pm 0.42^{\mathrm{a}}$ & $8.3 \pm 0.42^{\mathrm{a}}$ & $8.2 \pm 0.28^{\mathrm{a}}$ & $8.5 \pm 0.56^{\mathrm{a}}$ & $8.5 \pm 0.31^{\mathrm{a}}$ \\
\hline $30 \% \mathrm{LF}$ & $6.7 \pm 0.42^{\mathrm{b}}$ & $7.0 \pm 0.56^{\mathrm{bcd}}$ & $5.5 \pm 0.36^{\mathrm{d}}$ & $5.5 \pm 0.42^{\mathrm{d}}$ & $6.5 \pm 0.14^{\mathrm{b}}$ & $6.1 \pm 0.42^{\alpha d}$ \\
\hline $30 \% \mathrm{BF}$ & $6.8 \pm 0.28^{\mathrm{b}}$ & $5.4 \pm 0.14^{\mathrm{e}}$ & $6.5 \pm 0.14^{\mathrm{bc}}$ & $7.3 \pm 0.19^{b}$ & $6.6 \pm 0.35^{\mathrm{b}}$ & $6.7 \pm 0.14^{\mathrm{bcd}}$ \\
\hline $30 \% \mathrm{OF}$ & $7.3 \pm 0.70^{\mathrm{b}}$ & $7.3 \pm 0.19^{b c}$ & $7.0 \pm 0.28^{\mathrm{b}}$ & $6.5 \pm 0.24^{\mathrm{c}}$ & $7.0 \pm 0.28^{\mathrm{b}}$ & $7.2 \pm 0.56^{\mathrm{b}}$ \\
\hline $15 \% \mathrm{LF}+15 \% \mathrm{BF}$ & $6.2 \pm 0.58^{\mathrm{b}}$ & $6.6 \pm 0.12^{\mathrm{d}}$ & $6.8 \pm 0.56^{\mathrm{b}}$ & $6.4 \pm 0.36^{\mathrm{c}}$ & $6.5 \pm 0.15^{\mathrm{b}}$ & $6.5 \pm 0.15^{\mathrm{bcd}}$ \\
\hline $15 \% \mathrm{BF}+15 \% \mathrm{OF}$ & $6.5 \pm 0.45^{\mathrm{b}}$ & $6.8 \pm 0.21^{\alpha d}$ & $6.0 \pm 0.25^{\mathrm{\alpha d}}$ & $6.0 \pm 0.32^{\alpha d}$ & $6.7 \pm 0.49^{\mathrm{b}}$ & $6.3 \pm 0.22^{\mathrm{dd}}$ \\
\hline $15 \% \mathrm{LF}+15 \% \mathrm{OF}$ & $6.3 \pm 0.21^{\mathrm{b}}$ & $6.6 \pm 0.28^{\mathrm{d}}$ & $5.5 \pm 0.19^{d}$ & $6.0 \pm 0.21^{\mathrm{dd}}$ & $5.5 \pm 0.36^{\mathrm{c}}$ & $6.0 \pm 0.14^{\mathrm{d}}$ \\
\hline $10 \% \mathrm{LF}+10 \% \mathrm{BF}+10 \% \mathrm{OF}$ & $6.4 \pm 0.25^{\mathrm{b}}$ & $7.5 \pm 0.18^{b}$ & $6.5 \pm 0.28^{\mathrm{bc}}$ & $6.2 \pm 0.28^{\mathrm{c}}$ & $7.2 \pm 0.12^{\mathrm{b}}$ & $6.8 \pm 0.35^{\mathrm{bc}}$ \\
\hline
\end{tabular}

*Means $( \pm$ stand ard error) $\quad$ with same letter within column are not significantly different $(\mathrm{p}<0.05)$. Lupin flour, BF:Buckwheat flour, OF:Oat flour 
Table 8. Results of Sensory Analysis of Yufka Samples*

\begin{tabular}{|c|c|c|c|c|c|}
\hline & Appearance & Elasticity & Mouthfeel & Taste and odor & $\begin{array}{c}\text { Overall } \\
\text { acceptability }\end{array}$ \\
\hline Control & $8.2 \pm 0.28^{\mathrm{a}}$ & $8.5 \pm 0.42^{\mathrm{a}}$ & $8.0 \pm 0.56^{\mathrm{a}}$ & $8.3 \pm 0.42^{\mathrm{a}}$ & $8.3 \pm 0.28^{\mathrm{a}}$ \\
\hline $30 \% \mathrm{LF}$ & $4.5 \pm 0.31^{\mathrm{d}}$ & $4.5 \pm 0.31^{\mathrm{e}}$ & $5.5 \pm 0.33^{\mathrm{dd}}$ & $6.0 \pm 0.56^{\mathrm{d}}$ & $5.0 \pm 0.49^{\mathrm{d}}$ \\
\hline $30 \% \mathrm{BF}$ & $6.5 \pm 0.14^{b}$ & $6.8 \pm 0.28^{\mathrm{bc}}$ & $5.4 \pm 0.43^{\mathrm{d}}$ & $5.8 \pm 0.48^{\mathrm{d}}$ & $6.2 \pm 0.56^{\mathrm{bc}}$ \\
\hline $30 \% \mathrm{OF}$ & $6.5 \pm 0.42^{b}$ & $6.5 \pm 0.42^{\mathrm{c}}$ & $6.6 \pm 0.28^{b}$ & $6.8 \pm 0.53^{\mathrm{bc}}$ & $6.7 \pm 0.14^{\mathrm{b}}$ \\
\hline $15 \% \mathrm{LF}+15 \% \mathrm{BF}$ & $6.5 \pm 0.15^{\mathrm{b}}$ & $7.0 \pm 0.55^{\mathrm{bc}}$ & $6.4 \pm 0.43^{\mathrm{bc}}$ & $6.5 \pm 0.15^{\mathrm{bcd}}$ & $6.6 \pm 0.38^{b}$ \\
\hline $15 \% \mathrm{BF}+15 \% \mathrm{OF}$ & $6.0 \pm 0.25^{\mathrm{bc}}$ & $7.0 \pm 0.39^{\mathrm{bc}}$ & $6.0 \pm 0.25^{\mathrm{bcd}}$ & $7.0 \pm 0.42^{\mathrm{b}}$ & $6.5 \pm 0.45^{\mathrm{bc}}$ \\
\hline $15 \% \mathrm{LF}+15 \% \mathrm{OF}$ & $5.5 \pm 0.49^{\mathrm{c}}$ & $5.5 \pm 0.28^{\mathrm{d}}$ & $5.7 \pm 0.63^{\mathrm{bcd}}$ & $6.0 \pm 0.36^{\mathrm{dd}}$ & $5.6 \pm 0.22^{\mathrm{dd}}$ \\
\hline $10 \% \mathrm{LF}+10 \% \mathrm{BF}+10 \% \mathrm{OF}$ & $6.0 \pm 0.31^{\mathrm{bc}}$ & $7.5 \pm 0.14^{\mathrm{b}}$ & $6.0 \pm 0.31^{\mathrm{bcd}}$ & $7.0 \pm 0.26^{b}$ & $6.8 \pm 0.60^{\mathrm{b}}$ \\
\hline
\end{tabular}

*Means $( \pm$ stand ard error) $\quad$ with same letter within column are not significantly different $(\mathrm{p}<0.05)$. Lupin flour, BF:Buckwheat flour, OF:Oat flour

\section{Conclusions}

In the present study, bazlama and yufka (Turkish flat breads) enriched with LF, BF, OF and the effects of these flours on the physical, chemical and sensory properties of breads were investigated. The rich composition of LF, BF and $\mathrm{OF}$ improved the nutritional quality of bazlama and yufka samples in terms of ash, protein and mineral content ( $\mathrm{Ca}, \mathrm{Cu}, \mathrm{Fe}, \mathrm{Mg}, \mathrm{Mn}, \mathrm{P}, \mathrm{K}, \mathrm{Zn}$ ). The yellow color of LF and dark color of BF directly affected the surface color of bazlama and yufka. It can be concluded from the results of this study that acceptable bazlama and yufka can be produced by the addition of the $\mathrm{LF}, \mathrm{BF}$ and $\mathrm{OF}$ at equal ratio $(10 \%)$.

\section{REFERENCES}

[1] E. Elgün, S. Türker,. and N. Bilgiçli, N., Tahıl Ürünleri Teknolojisi, Selçuk University Food Engineering Department, Turkey, 2007.

[2] M. Salehifar, M.S. Ardebili, M.H. Azizi, "Effect of wheat flour protein variations on sensory attributes, texture and staling of Taftoon bread", Cienc. Technol. Aliment, Campinas, vol. 30, no. 3, pp. 833-837, 2010.

[3] A. Başman and H. Köksel, "Properties and composition of Turkish flat bread (Bazlama) supplemented with barley flour and wheat bran", Cereal Chemistry, no.76, pp. 506-511, 1999.

[4] A. Başman, and H. Köksel, "Effects of barley flour and wheat bran supplementation on the properties andcomposition of Turkish flat bread (Yufka)", European Food Research and Technology, no. 212, pp. 198-202, 2001.

[5] H. Levent, N. Bilgiçli, B. Madenci, "The usage of resistant starch in traditional flat breads, bazlama, lavash and yufka", III. Geleneksel Gidalar Sempozyumu, pp. 303-306, 2012.

[6] P. Rayas-Duarte, C.M. Mock, L.D. Satterlee, "Quality ofspaghetti containing buckwheat, amaranth, and lupin flours", Cereal Chemisty, no. 73, pp. $381-387,1996$.

[7] D.S. Petterson, Composition and food uses of lupins, In: J.S. Gladstones, C.A. Atkins and J. Hamblin (Eds.), Lupins as Crop Plants: Biology, Production and Utilization, Cab International, Wallingford, Oxfordshire, U.K., pp. 353-384, 1998.
[8] G. Dervas, G. Doxastakis, S. Zinoviadi, N. Triandatafillakos, "Lup in flour addition to wheat flour doughs and effect on rhelogical properties", Food Chemistry, no. 66, pp. 67-73, 1999.

[9] M.A. Faluyi, X.M. Zhou, F. Zhang, S. Leibovitch, P. Migner, D.L. Smith, "Seed quality of sweet white lupin (Lupinus albus) and management practice in eastern Canada", European Journal of Agronomy, no. 13, pp. 7-37, 2000.

[10] C. Huyghe, "White lupin (Lupinus albus L.)", Field Crops Research, no. 53, pp. 147-160,1997.

[11] D.S. Petterson, J.B. Mackintosh, The chemical composition and nutritive value of Australian grain legumes, Grains Research and Development Corporation, Canberra,1994.

[12] G. Bonafaccia, M. Marocchini, I. Kreft, "Composition and technological properties of the flour and bran from common and tartary buckwheat", Food Chemistry, no. 80, pp. 9-15, 2003.

[13] V. Skrabanja, I. Kreft, T. Golob, M. Modic, S. Ikeda, K. Ikeda et al. "Nutrient content in buckwheat milling fractions", Cereal Chemistry, no. 81, pp. 172-176, 2004.

[14] I. Kreft, N. Fabjan, K. Yasumoto,'Rutin content in buckwheat (Fagopyrum esculentum Moench) food materials and products", Food Chemistry, no. 98, pp. 508-512, 2006.

[15] B. Havsreen, "Flavonoids, a class of natural products of high pharmacological potency", Biochemical Pharmacology, no. 32, pp. 1141-1148, 1983.

[16] B.D. Oomah, G. Mazza, "Flavonoids and antioxidative activities inbuckwheat", Journal of Agricultural and Food Chemistry, no. 44,pp. 1746-1750, 1996.

[17] N. Fabjan, J. Rode, J.I. Kosir, Z. Wang, Z. Zhang, I. Kreft, I., "Tartary buckwheat(Fagopyrum tataricum Gaertn.) as a source of dietary rutin and quercitrin", Journal of Agricultural and Food Chemistry, no. 51, pp. 6452-6455, 2003.

[18] A. Lazaridou, C.G. Biliaderis, M.S. Izydorczyk, Cereal beta-glucans: structures, physical properties, and physiological functions, In: Biliaderis, C.G.,Izydorczyk, M.S. (Eds.), Functional Food Carbohydrates, CRC Press, Boca Raton, pp. 1-72, 2007.

[19] M.S. Butt, M. Tahir-Nadeem, M.K.I. Khan, R. Shabir, M.S. Buut, "Oat:Unique among the cereals", Eur J Nutr no. 47, pp. 68-69, 2008.

[20] C.S. Brennan, L.J. Cleary, "The potential use of cereal $(1 \rightarrow 3,1 \rightarrow 4)$-beta-Dglucans as functional food ingredients", Journal of Cereal Science, no. 42, pp. 1-13, 2005. 
[21] S. Karppinen, K. Liukkonen, A. Aura, P. Forssell, K. Poutanen, "In vitro fermentation of polysaccharides of rye wheat and oat brans and inulin by human faecal bacteria", Journal of the Science of Food and Agriculture, no. 80, pp. 1469-1476, 2000.

[22] Y. Coşkuner, E. Karababa, "Studies on the quality of turkish flat breads based on blends of triticale and wheat flour", International Journal of Food Science and Technology, no. 40, pp: 469-479, 2005.

[23] B. Madenci, S. Türker, N. Bilgiçli, Effect of some dairy by product on physical, chemical and sensory properties of lavash bread, III. Geleneksel Gidalar Sempozyumu, pp. 309-312, 2012.

[24] B.E. Akbas, Mısır ekmeğinin bazı özellikleri ve yapım yöntemlerinin fitik asit miktarı üzerine etkileri, M. Thesis, Ankara University, Food Engineering Department , Ankara, Turkey, 2000.

[25] AACC, Approved Methods of the American Association of Cereal Chemists, 8th Ed., St. Paul, MN, 1990.

[26] H. Bubert, W.D. Hagenah, Detection and measurement, In: P. W. J. M. Boumans (Ed.), Inductively coupled plasma emission spectroscopy, New York: Wiley-Interscience Publishers, 1987.

[27] G. Doxastakis, I. Zafiriadis, M. Irakli, H. Marlani, C. Tananaki, "Lupin, soya and triticale addition to wheat flour doughs and their effect on rheological properties", Food Chemistry, no. 77,pp. 219-227, 2002.

[28] M. Yorgancılar, E. Atalay, M. Babaoğlu, Acılı̆̆ı giderilmiş termiye tohumlarının (lüpen= lupinus albus 1.) mineral içeriğì" Selçuk Tarım ve Gıda Bilimleri Dergisi, vol. 23, no. 50, pp.10-15, 2009.

[29] N. Bilgiçli, "Effect of buckwheat flour on chemical and functional properties of tarhana", LWT-Food Sci. Tech. no. 42, pp. 514-518, 2009.
[30] G. Yıldı, G., Karabuğday ununun (Fagopyrum esculentum Moench) ununun geleneksel Türk ekmeklerinde kullanılma imkanları üzerine araştırmalar, M. Thesis, Selçuk University, Food Engineering Department, Master Thesis, Konya, Turkey, 2009.

[31] V. Jayasena, P. Leung, S.M. Nasar-Abbas, Development and Quality evaluation of lupin-fortified instant noodles, Prooceedings of the 12th International Lup in Conference, Fremantle, Western Australia, 2008.

[32] D. Ballester, P. Carreno, X. Urritia, E. Yanez, "Chemical Composition and Nutritional Quality of Sugar Cookies Containing Full-Fat Sweet Lupine Flour (L. albus cv Multolupa)", Journal of Food Science, vol. 51 no.3, pp. 645-646, 1986.

[33] A. Torres, J. Frias, M. Granito, M. Guerra, C. Vidal-Valvarde, "Chemical, biological and sensory evaluation of pasta products supplemented with alpha-galactoside -free lupin flours", Journal of the Science of Food and Agriculture, vol. 87, no. 1, pp. 74-81, 2007.

[34] A.Y. Tamime, D.D. Muir, M.N.I. Barclay, M. Khaskheli, D. McNulty, "Laboratory-made Kishk from wheat, oat and barley:2. Compositional quality and sensory properties", Food Research International, vol. 30, no. 5, pp. 319-326, 1997.

[35] İ. Çelik, F. Işık, O. Gürsoy, "Couscous, a traditional Turkish food product: production method and some applications for enrichment of nutritional value", Int J Food Sci Tech, no. 39, pp. 263-269, 2004.

[36] L.Y. Lin, H.M. Liu, Y.W. Yu, S.D. Lin, J.L. Mau, "Quality and antioxidant property of buckwheat enhanced wheat bread", Food Chemistry, no. 112,pp. 987-991, 2009.

[37] H.G. Marshall, Y. Pomeranz, Buckwheat: description, breeding, production, and utilization, In: Y. Pomeranz (Ed.), Advances in cereal science and technology, St. Paul: AACC, 1990. 